\title{
PRELIMINARY RESULTS ON USE OF THE OPEN NUCLEUS BREEDING SCHEME FOR IMPROVING MILK PRODUCTION OF EGYPTIAN BUFFALO
}

\author{
A.A. Nigm ${ }^{1}$, S.A. Abdel-Salam ${ }^{1}$, Manal Elsayed ${ }^{2}$, R.R. Sadek ${ }^{1}$ and A.S. \\ Abdel-Aziz ${ }^{1}$ \\ 1- Department of Animal Production, Faculty of Agriculture, Cairo University, \\ Gamaa Street, Giza, 12613, Egypt, 2- Department of Animal Production, Faculty of \\ Agriculture, Ain Shams University, Shubra El-Kheima, Cairo, Egypt.
}

\section{SUMMARY}

The objectives of this paper were to investigate simultaneously the effect of combinations of population size (z), nucleus size (p) and fraction of nucleus dams born in base $(x)$ on expected genetic gain of the open nucleus breeding scheme (ONBS). The impact of using artificial insemination on enhancing genetic gain was also studied. Simulation technique was used to generate a population of buffaloes with one milk record for each buffalo. The average of milk yield assumed was 1763 $\mathrm{kg}$. A total number of 848 records of 676 buffalo cows were used to estimate parameters used to simulate populations of different sizes (10, 25 and 50 thousand). Genetic gain per generation $(G)$ and annual genetic gain $(G / Y)$ were calculated according to James (1977).

G ranged from 139 to $186 \mathrm{~kg}$ of milk and G/Y ranged from 24.1 to $32.1 \mathrm{~kg}$ of milk/year. The highest gain was obtained when the population size was 25000 cows, out of which the best 0.05 formulated the nucleus and the fraction of nucleus dams transferred from the base was 0.50. Using artificial insemination (AI) enhanced the expected genetic gain which was much higher than that obtained using natural insemination. G ranged from 172 to $277 \mathrm{~kg}$ of milk and the annual genetic gain ranged from 30 to $48 \mathrm{~kg}$ of milk.

Keywords: Genetic gain, selection intensity, open nucleus scheme, simulation, Egyptian buffalo

\section{INTRODUCTION}

The open nucleus breeding scheme (ONBS) offers a simple procedure for producing and disseminating breeding stock of known value (Cunningham, 1979 and 1987; Hinks, 1974 and 1977 and Jasiorowski, 1991). In developing countries one of the advantages is that nucleus scheme override any lack of infrastructure, such as communication, roads, education and commerce, and concentrate available funds and scientific resources in a few breeding units. Nucleus stocks should be open continuously to introduction of individuals of higher genetic merit from any source. This would help to reduce inbreeding levels.

Issued by The Egyptian Society of Animal Production 
Due to increased additive genetic variation as a result of differences between levels, expected genetic gain in open nucleus systems is more rapid than in equivalent single herds, provided more females than males need to be replaced. The greater selection differential on the dams of sires path in open nucleus systems compensates for the reduced differential on the sires of dams path (Muller and James, 1984). Hopkins (1978) reported that using more efficient selection strategies and short generation lengths in the nucleus would increase rates of gain.

Dixit and Sadana (1999a) studied ONBS in Murrah buffaloes and reported that the optimum level of nucleus size $(p)$, fraction of nucleus dams born in base $(x)$, fraction of base dams born in nucleus $(y)$ and proportion of males born used as sires (a) were $0.10,0.40,0.10$ and 0.01 respectively irrespective of the level of proportion of all females born used as dams $(b=0.90)$ and showed that the genetic gain was $140.81 \mathrm{~kg}$ of milk per generation or $24.36 \mathrm{~kg}$ milk per year which was $1.46 \%$ of the herd average.

In another study, Dixit and Sadana (1999b) on ONBS in Murrah buffaloes assumed the levels of $p, x, y, a$, and $b$ as $0.20,0.40,0.10,0.20$ and 0.80 , respectively, and reported that the genetic gain was $78.88 \mathrm{~kg}$ milk per generation or $13.64 \mathrm{~kg}$ milk per year which was $0.82 \%$ of the herd average.

Since there is a need for reliable records for genetic evaluation, computer simulation may be a way to generate records for assessing values, and test selection response for different breeding schemes.

This study aims at investigating the effect of combinations of population size $(z)$, nucleus size $(p)$ and fraction of nucleus dams born in base $(x)$ on expected genetic gain of the ONBS. The impact of using artificial insemination on genetic gain was also studied.

\section{MATERIAL AND METHODS}

\section{Generation of the simulated population of buffaloes}

Simulation technique was used to generate a population of buffaloes with one milk record for each buffalo. The average milk yield was assumed $1763 \mathrm{~kg}$. A total number of 848 lactation records of 676 Egyptian buffaloes recorded by Cattle Information System/Egypt (CISE) of Cairo University during the period from 1996 to 2003 were used to estimate various parameters (Table 1) which were used to simulate populations of different sizes.

Table 1. The estimates used in generating the simulated populations of buffaloes

\begin{tabular}{|c|c|c|}
\hline Parameter & Estimate & Reference \\
\hline Average milk yield (MY), kg & 1763 & CISE, 2003 \\
\hline Phenotypic standard deviation for MY, $\mathrm{kg}$ & 563 & CISE, 2003 \\
\hline Average generation interval, yr & 5.78 & Mourad, 1990 \\
\hline $\begin{array}{l}\text { No. of females mated per sire per year } \\
\text { under natural insemination }\end{array}$ & 50 & CISE, 2003 \\
\hline Heritability & 0.25 & $\begin{array}{l}\text { Weighted mean of heritabilities } \\
\text { in the Egyptian literature }\end{array}$ \\
\hline $\begin{array}{l}\text { No. of females mated per sire per year } \\
\text { under AI }\end{array}$ & 5000 & $\begin{array}{l}\text { Barkawi, 2004 (Personal } \\
\text { communication) }\end{array}$ \\
\hline
\end{tabular}

CISE: Cattle Information System/Egypt 
Populations were generated using Monte Carlo simulation procedure of SAS (1996) with assumed mean (0) and variance (1). Different population sizes were simulated for milk yield trait. Both additive genetic and residual effects were distributed normally. No fixed effects were simulated. The method was applied for only one generation. The generation interval was assumed to be 5.78 year. Number of females mated to every sire/year under natural insemination was 50 . Under artificial insemination, the number was assumed to be 5000 (Table 1).

Genotype of the animal was simulated by the formula (1) according to (Meuwissen, 1991):

$$
g_{i}=1 / 2 g_{s}+1 / 2 g_{d}+a_{i} \sqrt{0.5 h^{2} \sigma_{p}^{2}}
$$

Where:

$\mathrm{g}_{\mathrm{i}}, \mathrm{g}_{\mathrm{s}}$, and $\mathrm{g}_{\mathrm{d}}$ is the additive genetic value of individual $\mathrm{i}$, its sire and its dam, respectively;

$\mathrm{h}^{2}$ is the heritability in population $\left(\mathrm{h}^{2}=0.25\right)$;

$\sigma_{p}^{2}$ is the phenotypic variance;

$\mathrm{a}_{\mathrm{i}}$ is the random number from the distribution $\mathrm{N}(0,1)$,

The lactation of buffalo i was simulated by formula (2) according to (Meuwissen, 1991):

$Y_{i}=\mu+g_{i}+E_{i}$

and

$\mathrm{E}_{\mathrm{i}}=\sigma_{\mathrm{e}} \mathrm{a}_{\mathrm{i}}$

Where:

$Y_{i}$ is the lactation of the $i^{\text {th }}$ buffalo;

$\mathrm{g}_{\mathrm{i}}$ is the additive genetic value of individual $\mathrm{i}$;

$\mu$ is the average milk yield;

$\mathrm{E}_{\mathrm{i}}$ is the environmental effect of the $\mathrm{i}^{\text {th }}$ buffalo;

$\sigma_{\mathrm{e}}$ is the square root of the error variance;

$\mathrm{a}_{\mathrm{i}}$ is the random number from the distribution $\mathrm{N}(0,1)$.

\section{Estimation of breeding values for milk yield}

Breeding values were estimated using the Derivative - Free Restricted Maximum Likelihood (DF-REML) procedure (Meyer, 1998).

The breeding values of bulls and cows were evaluated using model (3)

$\mathbf{Y}_{\mathrm{ij}}=\boldsymbol{\mu}+\mathbf{A}_{\mathbf{i}}+\mathbf{O}_{\mathbf{j}}+\mathbf{e}_{\mathrm{ij}}$

Where:

$\mathrm{Y}_{\mathrm{ij}}=$ observation of lactation of the buffalo;

$\mu \quad$ is the overall mean,

$\mathrm{A}_{\mathrm{i}} \quad$ is additive genetic random effect of the individual $\mathrm{i}$,

$\mathrm{O}_{\mathrm{j}}$ is the fixed effect simulated at random after generating the data, $\mathrm{j}=1$ and 2 ,

$\mathrm{e}_{\mathrm{ij}}$ is the random residual effect. 


\section{Calculation of expected genetic gain in milk yield}

The parameters assumed for estimating the genetic response of the simulated open nucleus breeding scheme are shown in (Table 2). Genetic gain per generation and annual genetic gain were calculated using the methodology of James (1977). The method of calculating genetic gain depends on estimating the average genetic selection differentials of animals used in nucleus and base. The rate of progress as response to selection is modified by migration of genes between parts of the population with different mean breeding values i.e. from the nucleus to the base and vice versa. Thus, the ultimate genetic gain is given by a weighted average of the genetic selection differentials in nucleus and base, the weights being the gene migration rates from each part of the population to the other.

Table 2. Input variables for calculating genetic gain

\begin{tabular}{lcl}
\hline Item Description & Symbol & Value \\
\hline Heritability & $\mathrm{h}^{2}$ & 0.25 \\
Replacement rate & $\mathrm{r}$ & 0.20 \\
Fraction of total population in nucleus & $p$ & $0.01,0.05,0.10$ \\
Fraction of nucleus dams born in base & $x$ & $0.10,0.25,0.50$ \\
Fraction of base dams born in nucleus & $y$ & $0.01,0.05,0.10$ \\
Fraction of nucleus sires born in base & $v$ & 0.00 \\
Fraction of base sires born in nucleus & $w$ & $0.05,0.10,0.20,1.00$ \\
Proportion of all males born used as sires & $a$ & $0.01,0.02,0.05,0.10$, \\
& & 0.20 \\
Proportion of all females born used as dams & $b$ & 0.80 \\
Simulated population size & $\mathrm{Z}$ & $10000,25000,50000$ \\
\hline
\end{tabular}

Significance of differences among means of genetic gain resulting from applying different input variables was tested using Duncan's Multiple Range Test procedure (SAS, 1996).

\section{RESULTS AND DISCUSSION}

\section{Effect of combinations of population size (z), nucleus size (p) and fraction of nucleus dams born in base $(x)$}

The effect of combinations of $z, p$ and $x$ were tested simultaneously. The selection intensity in females $(b)$ was considered as 0.80 . The other three variables $a, w$ and $y$ were kept fixed because the strong selection intensity in males (a) will result in a higher genetic gain, the value of $w$ depends on $p$ and $a$ and the value of $y$ depends on $p$ and $b$.

Table 3 presents the values of expected genetic gain in response of different combinations of $z, p$ and $x$. The genetic gain per generation ranged from 139 to 186 $\mathrm{kg}$ of milk. The highest gain was obtained when the population size was 25000 cows, out of which the best 0.05 formulated the nucleus and the fraction of nucleus dams transferred from the base was 0.50 .

Within the same population sizes $(z)$ of 10000 and 25000 heads, genetic gain increased as nucleus size $(p)$ increased from 0.01 to 0.05 . In the population of 50000 heads, this increase was observed only when nucleus dams transferred from base $(x)$ 
were only 0.10 of the nucleus dams. Larger fractions of $x$ in larger populations would decrease the average breeding value of the nucleus and hence, the selection intensity. Also, genetic gain increased by reducing nucleus size from 0.10 to only 0.05 of the whole population in case of the 50 thousand-head-population, due to larger magnitude of selection differential. It is clear that nucleus size is of greater importance at populations of small size (10000 heads). Small nucleus size $(p)$, especially in small populations, would increase inbreeding. In a population of 50000 heads, increasing $p$ resulted in a continuous decrease in annual genetic gain.

Table 3. Expected genetic gain (G) of milk yield (kg) in the simulated buffalo population as affected by population size (z), nucleus size (p) and fraction of nucleus dams born in base $(x)$

\begin{tabular}{lcccc}
\hline & & \multicolumn{3}{c}{ Nucleus dams born in base $(\boldsymbol{x})$} \\
\cline { 3 - 5 } $\begin{array}{l}\text { Population } \\
\text { size (z) }\end{array}$ & $\begin{array}{c}\text { Nucleus size } \\
(\boldsymbol{p})\end{array}$ & $\mathbf{0 . 1 0}$ & $\mathbf{0 . 2 5}$ & $\mathbf{0 . 5 0}$ \\
\hline $\mathbf{1 0 0 0 0}$ & $\mathbf{0 . 0 1}$ & 139 & 151 & 156 \\
& $\mathbf{0 . 0 5}$ & 168 & 175 & 177 \\
& $\mathbf{0 . 1 0}$ & 172 & 175 & 175 \\
\hline $\mathbf{2 5 0 0 0}$ & $\mathbf{0 . 0 1}$ & 154 & 166 & 171 \\
& $\mathbf{0 . 0 5}$ & 175 & 183 & 186 \\
& $\mathbf{0 . 1 0}$ & 177 & 180 & 180 \\
\hline $\mathbf{5 0 0 0 0}$ & $\mathbf{0 . 0 1}$ & 176 & 182 & 184 \\
& $\mathbf{0 . 0 5}$ & 180 & 182 & 182 \\
& $\mathbf{0 . 1 0}$ & 173 & 171 & 168 \\
\hline
\end{tabular}

The proportion of all males born used as sires $(a)=0.05$; the proportion of all females born used as dams $(b)=0.80$; the fraction of base sires born in nucleus $(w)$ $=0.05$; and the fraction of base dams born in nucleus $(y)=0.01$.

Within the same population size, increasing fraction of nucleus dams born in base $(x)$ increased genetic gain. Increasing $x$ from 0.10 to 0.25 enhanced genetic gain remarkably. Further increase of $x$ from 0.25 to 0.50 resulted in negligible increase in genetic gain (Figure 1).

Similar trends of expected genetic gain in buffalo were reported by Dixit and Sadana (1999a) in the cooperative group breeding scheme commonly and successfully implemented in India. The authors used a very limited population size of only 125 cows. They assumed a nucleus of only 25 cows.

The annual genetic gain ranged from 24.1 to $32.1 \mathrm{~kg}$ of milk/year. These figures represent $1.4-1.8 \%$ of the population averages. The estimates are in agreement with those reported for buffaloes in India (Dixit and Sadana, 1999a and 1999b). 

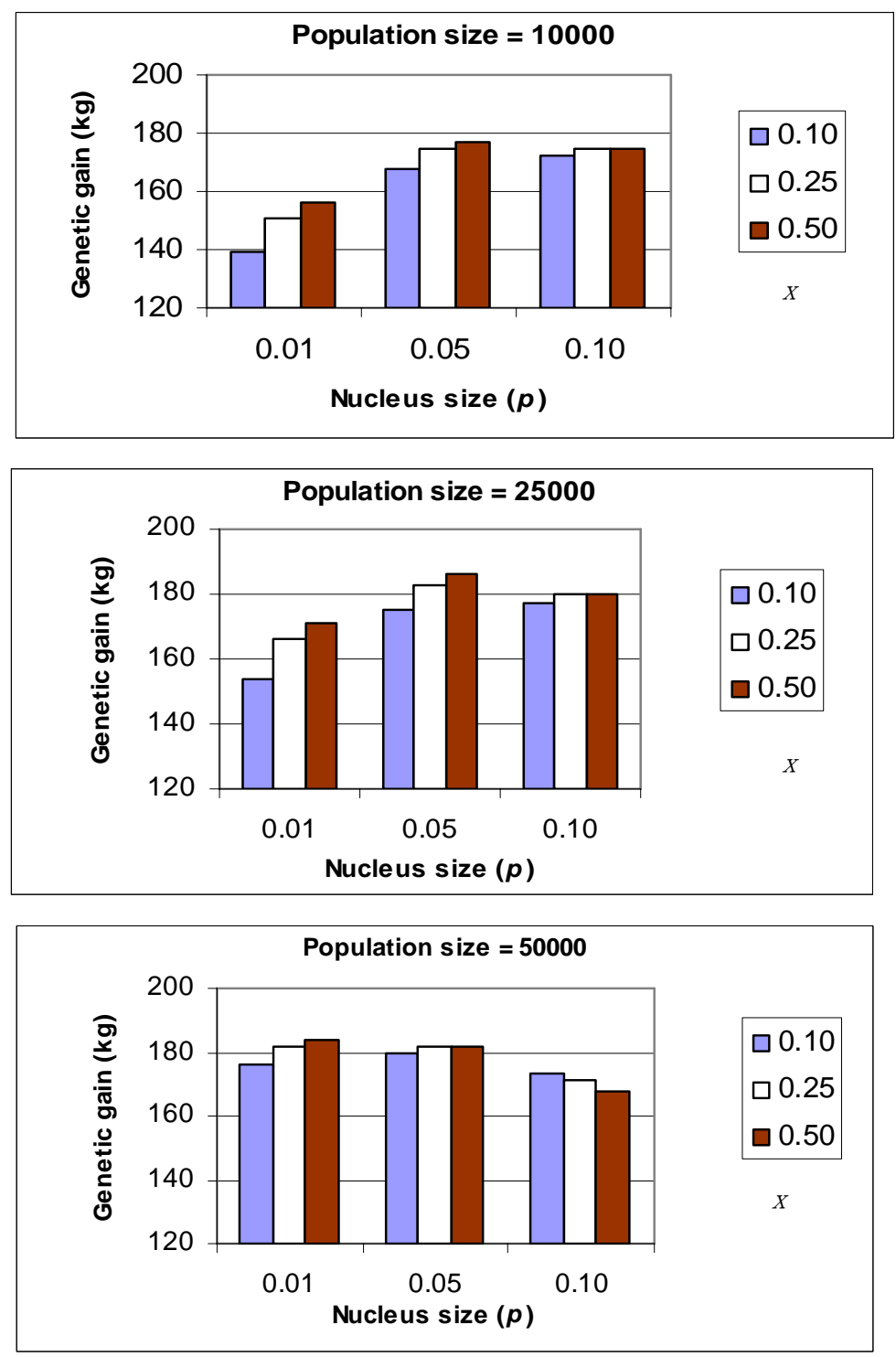

Figure 1. Genetic gain at variable nucleus size $(p)$ and nucleus dams born in base (x). 


\section{Use of artificial insemination (AI) in open nucleus breeding scheme}

In the previous parts of the discussion only natural insemination (NI) was considered in both nucleus and base. In this part, incorporating AI in ONBS to enhance expected genetic gain was investigated. As previously mentioned, it was assumed that one sire from the nucleus is mated yearly to 50 females in the base. Under AI, 5000 females in the base and nucleus were bred by one sire from the nucleus.

Table 4 shows the expected genetic gain as response of applying ONBS in the simulated population size $(z)$ with different levels of nucleus size $(p)$ and different proportion of males born used as sires $(a)$ when AI is used on the whole population.

The genetic gain ranged from 172 to $277 \mathrm{~kg}$ of milk and the annual genetic gain from 30 to $48 \mathrm{~kg}$ of milk which are much higher than those obtained using natural insemination.

The observed increase in genetic gain is due mainly to the higher selection intensity of males used as sires in AI. Also, AI will enable higher selection intensity even in small nucleus size of small populations. From the practical point of view, large number of breedable females could be inseminated by a smaller number of bulls with higher breeding values.

Table 4. Genetic gain (G) and annual genetic gain (G/Y) as affected by population size (z), nucleus size $(p)$ and proportion of males used as sires (a) under (AI)

\begin{tabular}{|lccc|}
\hline $\begin{array}{l}\text { Population } \\
\text { size (z) }\end{array}$ & $\begin{array}{c}\text { Nucleus size } \\
(\mathbf{p})\end{array}$ & $\begin{array}{c}\text { proportion of } \\
\text { males used as } \\
\text { sires (a) }\end{array}$ & Genetic gain (G, kg) \\
\hline $\mathbf{1 0 0 0 0}$ & $\mathbf{0 . 0 1}$ & 0.10 & 172 \\
& $\mathbf{0 . 0 5}$ & 0.02 & 204 \\
$\mathbf{2 5 0 0 0}$ & $\mathbf{0 . 1 0}$ & 0.01 & 219 \\
& $\mathbf{0 . 0 1}$ & 0.05 & 186 \\
& $\mathbf{0 . 0 5}$ & 0.01 & 212 \\
$\mathbf{5 0 0 0 0}$ & $\mathbf{0 . 1 0}$ & 0.01 & 227 \\
& $\mathbf{0 . 0 1}$ & 0.05 & 260 \\
& $\mathbf{0 . 0 5}$ & 0.01 & 277 \\
\hline
\end{tabular}

\section{CONCLUSION}

The present simulation study yielded reasonable preliminary results about use of the ONBS for genetic improvement of milk production in Egyptian buffalo. These results refer to the possibility of using ONBS. The annual genetic gain ranged from 24.1 to $32.1 \mathrm{~kg}$ of milk/year when using natural mating. These figures represented $1.4 \%$ to $1.8 \%$ of the population average. These percentages are comparable to gains obtained from other progeny testing schemes. Also, the study draws the attention of animal breeders and decision makers to important practical considerations, to be taken into account, when designing, establishing and exploiting ONBS. Among the interesting findings is the need for incorporating artificial insemination within ONBS. Beside accelerating genetic gain, AI would allow establishing small size nucleus 
herd(s) without lowering selection intensity among sires. Also, the study indicated the need for further extensive investigations to clarify more aspects of ONBS.

\section{REFERENCES}

Barkawi, A.H., 2004. Personal communication.

CISE, 2003. Periodical report. Cattle Information System/Egypt, Faculty of Agriculture, Cairo University, Egypt.

Cunningham, E.P, 1979. The importance of continuous genetic progress in adapted breeds. Report of the FAO Expert Consultation on Dairy Cattle Breeding in the Humid Tropics, pp. 35-41. FAO, Rome.

Cunningham, E.P., 1987. Crossbreeding Bos Taurus and Bos Indicus for milk production in the tropics. Animal Production and Health Paper 68: 15. FAO, Rome.

Dixit, S.P. and D.K. Sadana, 1999a. Response of single trait selection in open nucleus schemes for buffalo breeding. Indian J. Dairy Sci. 52: 17.

Dixit, S.P. and D.K. Sadana, 1999b. Efficiency of open nucleus breeding system in Murrah buffaloes. Indian J. Dairy Sci. 52: 117.

Hinks, C.J.M., 1974. The planning and organization of progeny testing with particular reference to numerically small populations and breeds of dairy cattle. Zeitschrift fur Tierzuchtung und Zuchtungsbiologie 91: 169. (Cited by Hinks, 1978).

Hinks, C.J.M., 1977. The development of nucleus herd selection programmes in dairy cattle breeding. Zeitschrift fur Tierzuchtung und Zuchtungsbiologie 94: 44. (Cited by Hinks, 1978).

Hinks, C.J.M., 1978. The use of centralized breeding schemes in dairy cattle improvement. Animal breeding Abstract 46: 291.

Hopkins, J.R., 1978. Some optimum age structures and selection methods in open nucleus breeding schemes with overlapping generations. Anim. Prod. 26:267.

James, J.W., 1977. Open nucleus breeding systems. Anim. Prod. 24: 287.

Jasiorowski, H.A., 1991. European animal husbandry: a model to adopt or reject by developing countries?. on the eve of the $3^{\text {rd }}$ millennium, the European challenge for animal production, EAAP Publication 48: 127. (CAB Abst.).

Meuwissen, T.H.E., 1991. The use of increased female reproductive rates in dairy cattle breeding schemes. Anim. Prod. 52: 21.

Meyer, K., 1998. DFREML (Derivative-Free Restricted Maximum Likelihood) package. Version 3.0 $\alpha .6^{\text {th }}$ World Cong. Genetic. Appl. Livest. Prod., Armidal.

Mourad, K.A., 1990. Buffaloes in Egypt. Proceedings of FAO Workshop on Buffalo Open Nucleus Breeding Schemes (ONBS), Shuman, Bulgaria.

Mueller, J.P. and J.W. James, 1984. Developments in open nucleus breeding systems. Al Segundo Congreso Mundial se Ovinos y Bovinos de Carne, Pretoria, SudJfrica page 204.

SAS Procedures Guide, Version 6.12. 1996. SAS Inst., Inc., Cary, NC. 
نتائج أولية عن إستخدام نظام النواة المفتوحة للتحسين الوراثى لإنتاج اللبن فى الجاموس المصرى

على عطية نجم¹، سامسح عبد الفتاح محمد عبد السلام، منال السيد، ربيع رجب صادق1، أحمد سعيد عبد العزيز 1

1- قسم الإتتاج الحيوانى - كلية الزراعة - جامعة القاهرة ـ شارع الجامعة ـ الجيزة - 12613- مصر

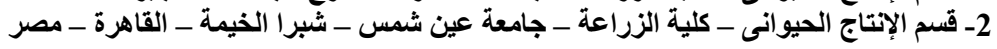

هدفت الدر اسة الى اختبار نأثير توليفة من عدة مستويات لثناثة عو امل معأ وهى حجم العشيرة وحجم النواة

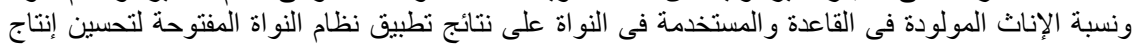

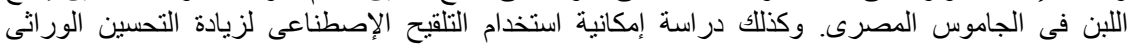

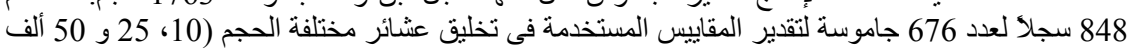

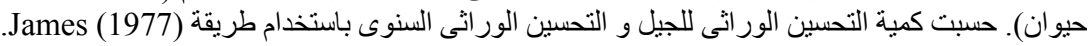

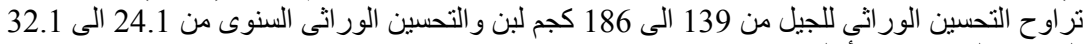

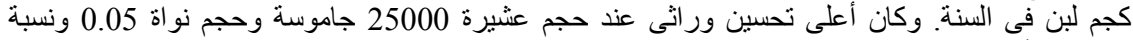
الإناث المأخوذة من القاعدة الى النواة التى

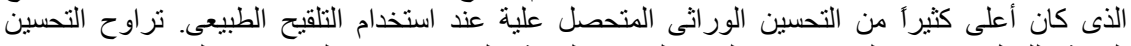
الوراثى للجيل من كن 172 الى 277 كجم لبن و التحسين الور اثى السنوى من 30 الى 48 كجم لبن. 